Pamiętnik Literacki 2020, 3, s. 235-242

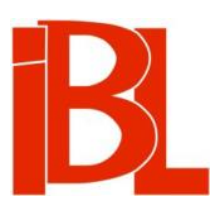

\title{
Performerzy nowoczesności.
}

Rec.: Magdalena Popiel, Świat artysty.

Modernistyczne estetyki tworzenia. Kraków 2018

Sabina Brzozowska 


\section{PERFORMERZY NOWOCZESNOŚCI}

Magdalena Po piel, ŚWIAT ARTYSTY. MODERNISTYCZNE ESTETYKI TWORZENIA. Kraków 2018. Towarzystwo Autorów i Wydawców Prac Naukowych „Universitas", ss. $320+12$ wklejek ilustr.

10 maja 2019 na Uniwersytecie im. Adama Mickiewicza w czasie spotkania poświęconego swojej najnowszej książce Magdalena Popiel sformułowała nieszablonową myśl, nie tylko wpisującą się w trwający od kilku dekad dyskurs o kondycji historii literatury, lecz przede wszystkim zmieniającą sposób myślenia o samych badaczach, włączająca ich bowiem w perspektywę zarezerwowana dotąd dla pisarzy ${ }^{1}$. Zuchwale i pociagająco wybrzmiały słowa o tym, że nie tylko artyści są zarządzającymi nieśmiertelnością, ale jesteśmy nimi także my, historycy literatury. Refleksja nad dwoma krzyżującymi się wątkami: problemem tożsamości historyka literatury i problemem współczesnego postrzegania historii literatury, zawiera w sobie - zdawać by się mogło - nieco anachroniczny pierwiastek perswazyjny, modelujący intencjonalność działalności badawczej i dydaktycznej, a wpisujący się $\mathrm{w}$ ukształtowane $\mathrm{w}$ modernizmie przekonanie o aktywnym udziale nauk humanistycznych w tworzeniu obrazów rzeczywistości. Zadaniem historyka literatury powinno być zatem poszukiwanie takich sposobów pośredniczenia między przeszłością a współczesnością, które byłyby formą aktualizacji dziedzictwa artystycz-

1 Spotkanie odbyło się w czasie konferencji Młoda Polska - Dwudziestolecie, zorganizowanej przez Zakład Literatury Pozytywizmu i Młodej Polski Instytutu Filologii Polskiej UAM w Poznaniu, 10 V 2019. 
nego sprzed lat i zarazem ukazywałyby realne pożytki płynące $z$ tej wiedzy dziś. Kluczem do współczesności, zdaniem autorki, jest estetyka; estetyzacja życia a deestetyzacja sztuki - to dwa istotne wektory warte prześledzenia, pytanie zaś, które się nasuwa, można sformułować następująco: co o człowieku mówi estetyka?

Świat artysty. Modernistyczne estetyki tworzenia to ważny i nowatorski głos o meandrach procesu twórczego, ale i o literaturze, głos będaccy konsekwentna, logiczną i oczekiwaną kontynuacją przemyśleń uczonej, znanych już chociażby z rozprawy Historia i metafora. O „Żywych kamieniach” Wacława Berenta (1989), z odczytania młodopolskich powieści poprzez kategorie tragizmu, ironii, groteski w książce Oblicza wzniosłości. Estetyka powieści młodopolskiej (1999), wreszcie z monografii Wyspiański. Mitologia nowoczesnego artysty (2007) czy cyklu artykułów poświęconych modernizmowi ${ }^{2}$. W pracy Magdaleny Popiel nie ma mowy o końcu modernistycznej formacji ani o definitywnym zmierzchu paradygmatu kultury pierwszych dekad XX w.; autorka dokonuje (re)konstrukcji pejzażu kulturowego modernizmu, uruchamiając wyobraźnię i emocje odbiorcy, kieruje uwagę bowiem na samego artystę, na jego głos ujawniający się także poza artefaktem - w listach, dziennikach, autobiografiach. Na plan pierwszy wysuwa się zatem perspektywa antropologiczna, niezmiennie atrakcyjna refleksja tożsamościowa i egzystencjalna nowoczesnego i ponowoczesnego artysty, spleciona $z$ wątkiem sprawczości, a wpisana obecnie w różne, wydawałoby się, że sprzeczne, jednak uzupełniające się wzajemnie rejestry: skomercjalizowane media przeciagają artystę w krag tandetnego ekshibicjonizmu, a zarazem - zauważa autorka - w czasach zachwiania autorytetu intelektualistów i polityków właśnie artyści zajmują ich miejsce, czyli „balansowanie między biegunami narcystycznego hedonizmu i politycznego zaangażowania, pozostaje istotnym rysem tożsamości artysty” (s. 14-15).

$\mathrm{Z}$ omawianej rozprawy wynika wszakże, iż zaproponowany przez uczona projekt - rekonstrukcja historii historii tworzenia jako wariantu kulturowej historii literatury - z jednej strony wyczerpuje swój potencjał wraz z początkiem ery nowych mediów, $z$ drugiej daje ponowoczesności pogłębioną refleksję na temat podmiotowości, potwierdza przydatność narracyjno-retorycznego, literaturoznawczego aparatu badawczego w rozpoznaniu procesu kreacyjnego jako określonego studium przypadku (case studies), a naukę o literaturze doposaża w narzędzia badań charakterystyczne dla nauk o sztuce (art base research). Wyjatkowość świadectw artystów modernizmu polega na powiązaniu zdolności odczuwania, formowania tożsamości, budowania relacji z Innym - ze zdarzeniami niemożliwymi, z „kontrfaktycznymi fabułami”, $z$ uniwersum nieograniczonej wyobraźni.

Popiel, posługując się pięknym, ale i meandrującym, nie stroniącym od metafory językiem, tropi ideę człowieka twórczego. W owym „testowaniu człowieka twórczego" (s. 16) ujawnia się dwubiegunowość i paradoksalność jego kondycji, z jednej strony uwikłanej w opresyjną kulturę, $z$ drugiej zaś naznaczonej pragnieniami, wola, imperatywem działania. Znana dychotomia postaw: artysta buntownik a artysta postrzegający rzeczywistość jako przestrzeń możliwości, wynika zatem

2 Większość tekstów składających się na tom Świat artysty. Modernistyczne estetyki tworzenia była wcześniej publikowana. Na potrzeby tomu artykuły zostały zmodyfikowane i rozszerzone, o czym poinformowano w Nocie wydawniczej. 
z dwojakiego rozumienia kultury - jako miejsca opresji i jako rezerwuaru wolności, czasoprzestrzeni idealnej dla performance’u. Autorka pisze:

Świat artysty. Modernistyczne estetyki tworzenia nie jest książką o performerach XXI wieku, lecz o performerach nowoczesności. Rainer Maria Rilke, Paul Cézanne, Auguste Rodin, Georg Simmel, Bruno Schulz, Stanisław Witkiewicz i Stanisław Ignacy Witkiewicz rozpoznawali swoją tożsamość artysty, przeglądając się w Innych. [s. 16]

Krakowska uczona podjęła zatem próbę opisania tych osobowości twórczych, u których aktywność artystyczna ściśle splata się z refleksją tożsamościową zawartą w literaturze dokumentu osobistego. Toteż istotne staje się nie tyle pytanie: „dlaczego coś jest dziełem sztuki?”, ile sytuujący się w ramach estetyki antropologicznej casus: „dlaczego ktoś jest artystą?” W centrum tejże problematyki znajduje się pojęcie pasji, utożsamiane raz ze splotem energii podtrzymywanej praca, to znów z cierpieniem, z męką tworzenia, która ma "cel i sens w katharsis” (s. 20). Figura artysty - scalającego estetykę $z$ antropologia, autopoietyczne narracje $z$ poczuciem niemocy i niespełnienia, pasję z pracowitością - utrwaliła się jako trop nowoczesności (i ponowoczesności). Temat artysty wraz z intrygująca koncepcją spisania historii historii tworzenia, nie będąca wszak ani tradycyjnie rozumianą historia literatury, ani historią sztuki czy historią idei - otwiera fascynującą, bo „żywą" i dynamiczna, perspektywę oglądu ważnego skrawka rzeczywistości, paradoksalnie opartą i na niedopowiedzeniach, i na intertekstualnym agonie na linii artysta-badacz. Toteż sama autorka unika arbitralności w sądach, pisze wprost o swoim projekcie badawczym jako rodzaju sprawozdania z prób dotarcia do „fragmentów wiedzy”, poszukiwaniu metody, „formułowaniu początków zdań”.

Popiel z nieukrywana sympatia wychwytuje i zarazem wzmacnia pojawiające się w światowej humanistyce głosy diagnozujące kulturę XX i XXI wieku. Szczególne miejsce w jej narracji zyskują m.in. historyk literatury George Steiner, filozof postmoderny Peter Sloterdijk czy Julia Kristeva. Omawianą rozprawe otwiera wywodzacy się z Rzeczywistych obecności Steinera motyw „domu luster”, metafora spotkania artystów i filozofów, oddająca dialogiczność i relacyjność zachodząca między filozofującymi poetami a obdarzonymi artystyczną wyobraźnią filozofami (Rilke - Simmel). Ową sieć zależności, agonicznych napięć dodatkowo zagęszczają findesiècle’owe przeświadczenie o kryzysie słowa jako nośnika znaczeń, podważenie zasady mimesis, gest fundamentalny zarówno dla literatury modernizmu, jak i dla awangardy oraz zastapienie tworzenia na wzór boski przez wynalazczość w stylu „posępnego błazna” i „grabarza sztuki”, Duchampa (s. 126). Steinerowski kult arcydzieła (Giotto - Picasso, Matisse; Goethe - Thomas Mann) wywodzi się z filozoficznego idealizmu, $z$ powiązania estetyki $z$ etyką, wydaje się też, że $z$ niego właśnie wynika wskazanie granicy epok, która nie przebiega „ani przed awangarda, ani po awangardzie, ale w poprzek niej" (s. 126).

Pojęcie estetyki antropologicznej ma z kolei swoje źródło w pracach Sloterdijka. Magdalena Popiel podkreśla inspirujący potencjał w kontrowersyjnej i - na pierwszy rzut oka - ekstremistycznej kategorii zwrotu antropotechnicznego, której skrajnym przykładem jest „życie-w-ćwiczeniu”, wsobna inżynieria ${ }^{3}$. Autorka przekonuje, że 
„teza o aktywności twórczej jako mechanizmie uruchamiającym system immunologiczny społeczeństwa" jest bardzo atrakcyjna (s. 19), tworzenie - przypomnijmy: wzmacniające układ odpornościowy społeczeństwa - obejmuje także działania „autopoietyczne”, a pod powtarzaniem, ćwiczeniem, antropotechnicznym treningiem kryje się pasja. Homo artista jest zatem homo immunologicus. Pozornie oswaja i powiedzmy przewrotnie - humanizuje koncepcję Sloterdijka zaczerpnięty z wiersza Rainera Marii Rilkego tytuł książki filozofa Musisz życie swe odmienić. Fragment utworu Archaiczny tors Apolla brzmi jak imperatyw moralny, wezwanie do działania, ale zarazem uwidacznia się w nim opresyjność kultury, nieznośny wymóg wypełniania obowiązków. Katarzyna Kuczyńska-Koschany w pracy Rilke poetów polskich, zestawiając panteizmy Rilkego i Leśmiana, za Arturem Sandauerem określiła postawę Rilkego mianem kobiecej, pasywnie poddającej się naturze ${ }^{4}$. Zważywszy dodatkowo na ten kontekst, tytuł rozprawy Sloterdijka nabrzmiewa wyraźna ambiwalencją: „życie-w-ćwiczeniu” oznaczać może powtarzalny proces zmagania się $\mathrm{z}$ niemożliwym.

Geniusz kobiecy Kristevej jest kolejną ważną inspiracją pracy Magdaleny Popiel. Od narracji artysty, „opowiadania życia”, poprzez relację historyka tropiącego artystę, aż po współczesną praxis (s. 18) - opowieść, której bohaterka jest Hannah Arendt: opowieść niechronologiczna, poszarpana, pełna oddaleń i zbliżeń, prowokuje do tożsamościowej refleksji, do „performance’u obecności” ${ }^{5}$; i w końcu uwalnia kategorię geniuszu od związanego z nim zwyczajowo pojęcia męskości.

Bohaterami Świata artysty są mężczyźni, ale jest to dominacja pozorna, zakłócona już we wstępie książki przywołaniem performance'u serbskiej artystki Mariny Abramović, która wyznaczyła sobie zadanie obecności i jako podmiotu, i jako artefaktu równocześnie w jednej z sal Museum of Modern Art w Nowym Jorku w 2010 roku. Jej prowokacja polegała na ,jawnej ekspozycji obecności” artysty i zaaranżowaniu spotkania $z$ Innym, doprowadzeniu do niemego dialogu. Przewagę męskich bohaterów narracji Świata artysty przede wszystkim jednak niweluje sama autorka, jej wyraźnie słyszalny głos i przenikliwe, uważne spojrzenie.

Magdalena Popiel nie ukrywa swej nieprzemijającej fascynacji mitologia artysty. W wieku XIX artyści sami podsycali swój mit, budowali własną legendę. Przywołane przez autorkę rozprawy jako przykład Nieznane arcydzieło (1831) Balzaka, opowiadanie o paryskich malarzach, jest niezmiennie przedmiotem refleksji najwybitniejszych postaci współczesnej humanistyki: Georges’a Didi-Hubermana, Huberta Damischa, Michela Leirisa, Michela Serres'a. Pisze o nim także Maria Poprzęcka w swej ostatniej pracy Impas. Opór, utrata, niemoc, sztuka $a^{6}$. Popiel wyeksponowała fenomen Nieznanego arcydzieła jako tekstu-zwierciadła, w którym przeglądali się artyści nie tylko przełomu XIX i XX w., ale też późniejsi. Admiratorem opowiadania Balzaka był m.in. Paul Cézanne, natomiast anegdotę o postimpresjoniście poruszonym dziełem o niespełnieniu opowiedział w liście do żony Rilke. Popiel komentuje:

s k i. Warszawa 2014. Zob. też tego autora: Reguty dla ludzkiego zwierzyńca. Odpowiedź na Heideggera list o humanizmie. Przeł. A. Ży c hlińs ki. „Przegląd Kulturoznawczy” 2008, nr 1.

4 K. Kuczyń s ka - Ko s ch a ny, Rilke poetów polskich. Torun 2017, s. 25.

5 J. Kris te va, Geniusz kobiecy: Hannah Arendt. Biografia. Przeł. J. Le vi n. Warszawa 2007.

6 M. Po przę c ka, Impas. Opór, utrata, niemoc, sztuka. Gdańsk 2019, s. 5. 
„To oczywiste, że [Rilke] pisze o sobie, stale i bez przerwy, a wprowadzenie w krag własnego świata innych artystów jest koniecznym zabiegiem autoanalizy” (s. 47).

Rilke nigdy nie spotkał Cézanne’a. Trudno jednak nie zauważyć, że to ten zafascynowany malarzem poeta uwidocznił - jak klarownie wyjaśnia autorka - „paradoksy estetyki Cézanne'a: sprzeczność nieimpresjonistycznego impresjonizmu, znaczenie koloru, który nie rozprasza przedmiotu, lecz utrwala go w kruchej materialności, a także przełamywanie opozycji sensualności i racjonalności natury i sztuki” (s. 57).

Pomimo sceptycyzmu wobec rozpraszania energii twórczej na działania pozaartystyczne Rilke właśnie w listach sformułował myśl o ascetycznym, monastycznym wręcz heroizmie pracy Cézanne’a oraz podjął zagadnienie ambiwalencji moralnej wpisanej w całkowite oddanie sztuce, konieczności „wyjścia poza miłość” (s. 56), opuszczenia rodziny, skazania się na nomadyzm. Jaka receptę proponuje Rilke na nieczyste sumienie artysty? Usprawiedliwieniem dla życia jest doświadczenie estetyczne, uobecnienie afektu w sztuce.

Inny charakter miała relacja Rilkego z Rodinem. Autor Elegii duinejskich pracował u niego w charakterze sekretarza. W roku 1903 wydał studium o rzeźbiarzu. Zwykło się przyjmować, że spotkanie $z$ Rodinem stanowiło przełom w twórczości Rilkego, początek poezji rzeczy, Ding-Gedicht. Lecz - uporządkujmy fakty - to właśnie Auguste Rodin, bezpośrednio obecny w życiu Rilkego, „obudził w nim [...] świadomość, że trzeba wybrać jedno z dwojga: albo szczęście, albo sztukę"7. Wybór Rilkego jest znany: sztuka. Ale dzięki Rodinowi odkrył Rilke rzeczy, odkrył powierzchnie, faktury i formy; orzekł, że najważniejszą ze sztuk modernizmu jest rzeźba, ponieważ najpełniej oddaje sprzeczności epoki, prowokuje do przenikania w głębię, pod powierzchnię, a także do interakcyjności form, przecinania się płaszczyzn; prawdziwym laboratorium rzeźby jest ciało.

Popiel w spotkaniach artystów (i filozofów) naświetla nie dezaktualizujący się splot wątków egzystencjalnych i estetycznych; śledzi formowanie się idei: oto Rodinowskie rzeźby bez rąk „stanowią przykład możliwej struktury, która wyrasta w poszukiwaniu nadmiaru w tym, co naturalne, i odnajdywania nowego ładu w tym, co nie-naturalne” (s. 77), natomiast z Rodinowskiej estetyki gestu rodzi się nowoczesna świadomość ciała. Autorka pokazuje przewrotność narracji Rilkego o Rodinie. Poeta przecież nie napisał jego biografii, dał świadectwo obecności w sztuce, a opowieść o życiu artysty - jak dopowiada Popiel: „może być tylko fikcją” (s. 80).

Krakowska uczona w swojej książce poddała oglądowi nieoczywiste, trudno uchwytne i niejednoznaczne kategorie estetyczne, takie jak kaprys, wdzięk, nonszalancja, lekki, ciężki. Jej wybór wywieść można ze skierowania uwagi na te epoki, w których pojawiło się przyzwolenie, by język nie pełnił swego prymarnego zadania, czyli komunikacji, a myśl mogła meandrować i zapuszczać się w boczne ścieżki ${ }^{8}$. Wejście do słownika estetyki pojęcia: Je ne sais quoi, oznacza zgodę na

$7 \quad$ A. Rog als k i, Rainer Maria Rilke religijny piewca świata widzialnego. W zb.: „Do Polski przyjadę...” Rainer Maria Rilke w oczach krytyki polskiej. Wybór, oprac. M. Zy b u ra. Wrocław 1995, s. 108. Cyt. za: Ku czyńs ka-Ko s chany, op. cit., s. 307.

8 Zob. G. Poulet, Metamorfozy czasu. Szkice krytyczne. Wybór J. Błońs ki, M. Głowińs ki. Przedm. J. Błońs ki. Warszawa 1977, s. 406. 
obecność w naszym zasobie leksykalnym takich określeń, które - choć nieprecyzyjne i wieloznaczne - wpisują się doskonale w dialog kultury. Autorka rekonstruuje zatem historię kaprysu w sztuce, od heterogenicznych, swobodnych kompozycyjnie, nawiązujących do technik kolażu, miejskich pejzaży fantastycznych z w. XVII, poprzez eksplorujący ludzką psychikę ciemny kaprys w stylu Piranesiego i Goi, aż po steoretyzowanie pojęcia przez Oskara Wilde'a w Dialogach o sztuce. Kaprys stał się wówczas zaprzeczeniem mentalności mieszczańskiej, negacją przewidywalności i nudy dnia powszedniego. Równocześnie jednak Popiel burzy linearność swojej narracji i przypomina odbiorcy, że wszedł za nią do „domu luster”, do historii kaprysu wprowadza zatem dialog kulturowy współczesnego historyka sztuki Georges'a Didi-Hubermana ze zmarłym w 1929 r. twórcą koncepcji Nachleben der Antike, Aby Warburgiem, o metamorfozach obrazu kobiecego ciała, o wdzięku nimf ${ }^{9}$; przywołuje błyskotliwą anegdotę o bezczelności z Dziennika Witolda Gombrowicza, by uzmysłowić, jak można zbudować paradoks. Warto Gombrowiczowską historyjkę przytoczyć:

Pewna moja znajoma opowiadała mi przed wojną, że kiedy pili podwieczorek na werandzie, przyszedł stryj Szymon. - Jak to - zapytałem - przecież Szymon od pięciu lat leży na cmentarzu? - Ano właśnie powiedziała - przyszedł $\mathrm{z}$ cmentarza, w tym samym garniturze, w którym go pochowaliśmy, przywitał się, siadł, napił się herbaty, pogawędził trochę o urodzajach i odszedł na cmentarz. - Jak to, a wy nic na to?!... - Cóż chcesz, mój drogi, wobec takiej be z c zeln o ś ci... ${ }^{10}$ [cyt. na s. 107]

W komentarzu do cytatu autorka pokazuje mechanizm scalania sprzeczności: zabawnej anegdoty i filozofii kondycji ludzkiej, posługując się opozycyjnymi kategoriami: lekki - ciężki; egzystencja i poznanie rozpościerają się pomiędzy biegunami „głupkowatej lekkomyślności” a „brzemieniem bytowania” (s. 109).

Termin „kaprys” wprowadził do historii kultury Giorgio Vasari. Pierwotne znaczenie pojęcia było jednak pejoratywne, charakteryzowało sztukę, która nie przestrzegała reguł naśladowania natury, $z$ czasem zaś zaczęło być kojarzone $z$ takimi prądami w sztuce, w których dominował pierwiastek hedonistyczny. Hybrydyczność terminu trafnie zobrazował Georg Simmel. W pracy Magdaleny Popiel postać niemieckiego filozofa i socjologa pojawia się tuż obok Rilkego. Znali się, bywali u siebie i, być może, wzajemnie się inspirowali w rozpoznawaniu fenomenu rzeźb Rodina. Związane $z$ właściwościami materii opozycyjne pojęcia: lekki - ciężki, w poglądach Simmla znalazły odbicie w estetyczno-antropologicznej parze: wdzięk - godność (powaga). Chociaż filozof wyżej cenił ów trud, opór materii, pozwalający jednostce

Urastającą do rangi mitu praca A. W a rbu rga jest nieukończony Atlas Mnemosyne, w którym jedno z kluczowych miejsc zajmuje obraz Nimfy. W roku 2010 „w Museo Reina Sofia w Madrycie (a następnie w centrach sztuki współczesnej w Hamburgu i Karlsruhe) odbyła się fascynująca wystawa Atlas. Jak unieść świat na własnych barkach?, wymyślona i przygotowana przez Georges'a Didi-Hubermana (który, co prawda, typowym kuratorem nie jest). Organizuje ją metoda Warburga: zwracająca się ku temu, co fragmentaryczne, zapomniane, unieważnione, marginalne, traktująca na równi - jako pewne dokumenty - sztukę i nie-sztukę, skupiona na relacjach, nie zaś na obiektach. Dlatego na wystawie "pełnoprawne dzieła" sąsiadują z wydobytymi z niepamięci archiwaliami, również z notatkami czynionymi przez pisarzy i teoretyków" (https://www.dwutygodnik.com/artykul/3120-aby-warburg-i-jego-przybrane-dzieci.html 〈data dostępu: 6 IX 2019〉).

10 W. G o mbrowi c z, Dziennik 1961-1966. Kraków 1986, s. 243. 
formować się i ewoluować, to przecież przyczynił się do utrwalenia jednego z podstawowych mitów nowoczesnego świata: syntezy ciężkości i lekkości, kaprysu natury i kaprysu kultury. Autor Estetyki ciężkości uchwycił dwuznaczny charakter Wenecji, która okazuje się „miastem sztucznym, gdzie wszyscy poruszają się jak na scenie", a tym samym -

stała się [Wenecja] symbolem całkiem wyjątkowego porządku pośród form naszego pojmowania świata: oto powierzchnia, która porzuciła grunt, pozór, w którym nie żyje żaden byt, przedstawia się mimo wszystko jako coś kompletnego i substancjalnego, jako treść rzeczywiście przeżywanego życia ${ }^{11}$. [cyt. na s. 116]

Magdalena Popiel kończy swą monografię Zakopiańskim eksperymentem. Do Zakopanego prowadzi ją trop Witkiewiczów, ich fotografii, portretu podwójnego z 1911 r., fotografii, którą potraktować można i jako rodzaj dokumentu osobistego, i metaforycznie - jako portretu modernizmu, łączącego zmierzchającą dziewiętnastowieczność z nowoczesnością XX wieku. Fenomen Zakopanego opisuje przez pryzmat spostrzeżeń Witkiewiczów - i udaje jej się uniknąc stereotypowego efektu. Autorka wydobywa cała hybrydyczność, irracjonalność i dwuznaczność miejsca. W końcu oddaje głos Witkacemu, który proroczo umieścił Zakopane „między otchłanią komercjalizacji a wierchami Metafizycznej Dziwności Istnienia” (s. 284), między fikcją literacką a realnością.

W pracy Świat artysty. Modernistyczne estetyki tworzenia pięknie ogrywany jest cytat „Wszystko jest możliwe, bo "wszystko jest jeszcze do zrobienia"” (s. 360), nie tylko odsyłający do wolności artystycznej, ale wskazujący również na nowe wyzwania historyka literatury: piętrzący się materiał badawczy, inne perspektywy oglądu tekstów kultury, wyjątkowe znaczenie literatury dokumentu osobistego oraz - dodajmy - rosnąca tym samym rangę genetyki tekstu. Monografia Magdaleny Popiel wciagga, ale nie jest lekturą łatwą, łączy ciężkość z lekkością: ogromny bagaż erudycji z lotem inspirujących skojarzeń. Toteż drugim mottem wyłaniającym się ze znakomitej pracy krakowskiej badaczki, które odtąd towarzyszyć może pracy filologa-antropologa, jest cytat z Estetyki słowa Paula Valéry'ego: „Tylko Bogu zastrzeżona jest niewysłowiona jednia czynu i myśli. My - co innego, my musimy się trudzić [...]. Musimy tropić słowa, które nie zawsze istnieją, szukać jakichś chimerycznych zbieżności”"12 (cyt. na s. 110).

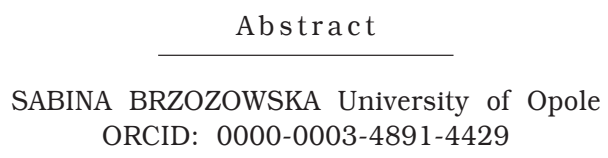

PERFORMERS OF MODERNITY

The text reviews of Magdalena Popiel's book Świat artysty. Modernistyczne estetyki tworzenia (The World of the Artist. Modernist Creative Aesthetics, Krakow 2018) and also attempts at tracing the intellectual construction that is a promising variant of cultural literary history-the story of the history of creative

11 G. Si m m el, Wenecja. W: Most idrzwi. Wybór esejów. Przeł. M. Łu k a s i e w i c z. Warszawa 2006, S. 188.

12 P. Valéry, Estetyka słowa. Wstęp M. Żurawski. Wybór A. Frybesowa. Przeł. D. Eska, A. Frybe s owa. Warszawa 1971, s. 127. 
process. The author directs the receiver's attention to the artist himself, to his voice that becomes audible also outside the artifact-in letters, diaries, autobiographies; thus The World of the Artist attempts to describe those creative individuality in whom artistic activity is closely linked to identity reflection contained in personal document literature. Performers of modernity in Magdalena Popiel's account are Rainer Maria Rilke, Paul Cézanne, Auguste Rodin, Georg Simmel, Bruno Schulz, Stanisław Witkiewicz, and Stanisław Ignacy Witkiewicz, all read through the prism of Peter Sloterdijk or Julia Kristeva. 